\title{
17. ORIGIN AND DIAGENESIS OF VOLCANIC-RICH SEDIMENTS FROM NORTH PACIFIC SEAMOUNTS, DSDP LEG 32 ${ }^{1}$
}

\author{
Ralph Moberly, Hawaii Institute of Geophysics, Honolulu, Hawaii \\ and \\ John B. Keene, Scripps Institution of Oceanography, La Jolla, California
}

\begin{abstract}
Volcanic sandstones were recovered from sites along seamount chains in the North Pacific. Three different modes of origin are proposed for them. The well-rounded, commonly weathered basalt sand and fine gravel from Kōko Guyot in the southern part of the Emperor Seamount chain is accompanied by whole and abraded shallow-water fossils, and is epiclastic, reworked at shallow depths. The fine, angular altered hyaloclastite sand from a submarine eruption of the Hawaiian Ridge west of Midway Islands is of turbidity current origin and helped to build an archipelagic apron.

The third site, among seamounts and guyots at the east end of the Mid-Pacific Mountains, has volcanic-bearing sediments of mixed texture, composition, and origin: partially epiclastic, partly hyaloclastic, and partly pyroclastic, and largely emplaced by turbidity currents that ponded between the volcanoes. The three types of sediment have had diagenetic histories that reflect, among other factors, their textures, glass, and carbonate content.
\end{abstract}

\section{INTRODUCTION}

Volcanic components of sedimentary rocks cored during Leg 32 of the Deep Sea Drilling Project help indicate the origin of those sediments. Representative thin sections are described from cores and samples from Site 308, at Koko Guyot, Emperor Seamounts; Site 311, near an unnamed seamount of the Hawaiian Ridge west of Midway Islands; and Site 313, within the Mid-Pacific Mountains west of Necker Ridge.

\section{KŌKO GUYOT}

Sites 308 and 309 are on the flanks of Kōko Guyot. Only a trace of sediment was recovered from Site 309. An Eocene sandy limestone from Site 308 is described below $(308-4-1,76 \mathrm{~cm})$.

This rock is an impure limestone that can be classified as an unsorted, volcanic-sandy, intraclastic, algal, and foraminiferal biosparite. Its singular features include rounded sand grains of altered basalt, an abundance of microspar, a high porosity from unfilled molds of former fossils of presumably aragonitic composition, and the presence of pellets along with fragments of bryozoans and mollusks, in addition to the algae, foraminifers, and intraclasts. The general composition is listed in Table 1.

Grains of volcanic origin make about $15 \%$ of the rock. Grain size is mainly coarse sand, with a mean greatest dimension of $0.63 \pm 0.39 \mathrm{~mm}$ for 100 grains measured

'Hawaii Institute of Geophysics Contribution No. 662. and increased $\times 1.15$ for a random slice that a thin section represents. Most grains are distinctly elongate in their thin-section projection, with width-to-length ratios mainly between 0.35 and 0.7 . Subrounded, rounded, and well-rounded grains are abundant. These categories would be even more predominant if the angular and subangular grains whose irregular edges appear to be the result of calcite replacement were discounted. Several of the more elongate rounded grains have been broken after rounding.

The volcanic grains are now mainly palagonite and montmorillonite, with chlorite, hematite, and zeolite less common. Except for magnetite or ilmenite opaques and some pyroxene microcrysts, little original minerals and no glass remain. Examples of virtually every texture common in basalt is present as ghosts: subophitic, felted, amygdular, porphyritic, apyric, aphanitic, and most commonly, intersertal. The palagonite suggests that part of the alteration of the volcanic rock took place between hot rock and water. The texture indicates a moderate amount of abrasion and sorting before deposition.

The variety of fossils contributed to the sediment is shown in Table 2, and Figures 1 and 2.

Codiacean algae predominate over red coralline algae about 6 to 1 . The fragments of codiacean algae are present mainly as molds, with the exterior outlined by drusy calcite and the interior tubes filled with micrite, pyrite, and microspar. The more slender and tapering outer tubes are perpendicular to the surface, and the larger, rounded internal tubes are in random positions, resembling those of Recent Halimeda. The largest grains of the sediment are fragments of these green algae. Some fragments are more than $6 \mathrm{~mm}$ in length, but most of 
TABLE 1

Composition of Impure Limestone

308-4-1, 76 cm (Eocene Kōko Guyot) Based on 1000 Points

Counted on Thin Section

\begin{tabular}{lr}
\hline Volcanic grains & 145 \\
Augite & 2 \\
Fossils & 219 \\
Intraclasts & 67 \\
Pellets & 46 \\
Spar $(>20 \mu \mathrm{m})$ & 172 \\
Microspar $(4<20 \mu \mathrm{m})$ & 288 \\
Micrite $(<4 \mu \mathrm{m})$ & 43 \\
Pyrite and other opaques & 15 \\
Phosphorite & 3 \\
Total & 1000 \\
\hline
\end{tabular}

TABLE 2

Biogenic Constituents of Impure Limestone 308-4-1, $76 \mathrm{~cm}$

(Eocene, Kōko Guyot) Based on 500 Points Counted on Thin Section

\begin{tabular}{lrc}
\hline Algae & 213 & $43 \%$ \\
Foraminifers & 129 & 26 \\
Bryozoans & 52 & 10 \\
Mollusks & 52 & 10 \\
Corals & 12 & 2 \\
Echinoids & 6 & 1 \\
Unknown & 36 & \multicolumn{7}{c}{} \\
\cline { 2 - 3 } Total & 500 & $100 \%$ \\
\hline
\end{tabular}

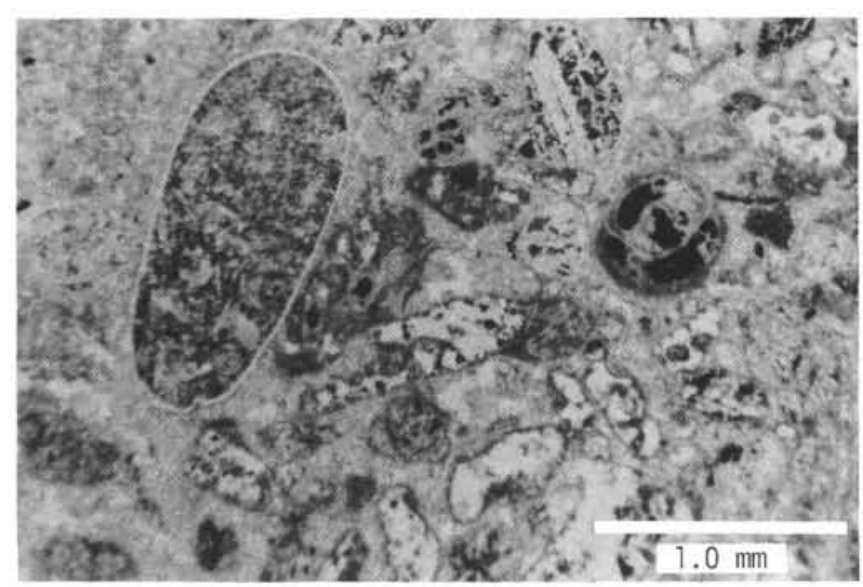

Figure 1. Photomicrograph, plain light, 308-4-1, $76 \mathrm{~cm}$. Eocene volcanic-sandy biosparite, Kōko Guyot. Scale bar in lower right is $1.0 \mathrm{~mm}$ long. Well-rounded basalt grain at left. Foraminifer at right partially filled with pyrite. Large area of microspar at left and between fossil (mainly algae) and volcanic grains at center.

them are about 0.2 to $0.3 \mathrm{~mm}$ thick and 0.3 to $0.7 \mathrm{~mm}$ long. Fragments of red algae are better preserved and are less than $0.5 \mathrm{~mm}$ long.

Benthonic foraminifers are of diverse types. Most tests are rotaliform or planispiral, and milioline tests are

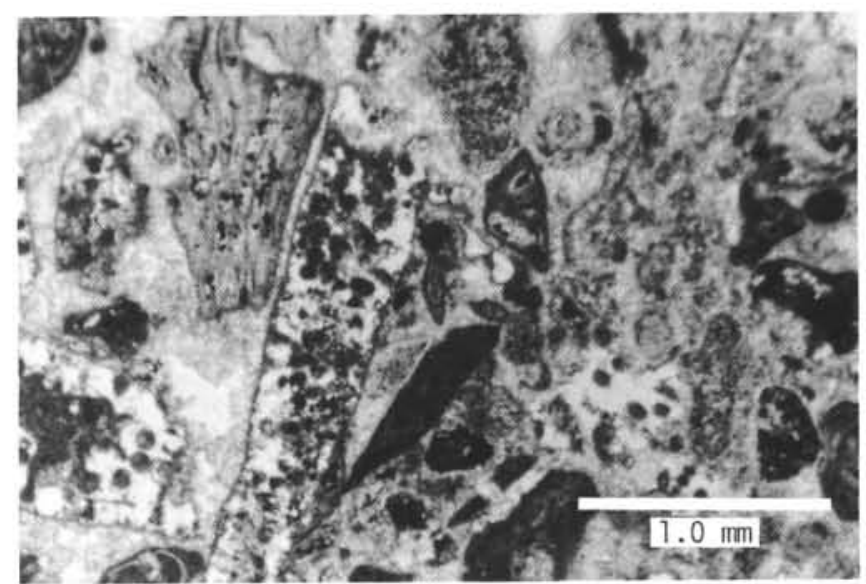

Figure 2. Photomicrograph, plain light, 308-4-1, $76 \mathrm{~cm}$. Eocene volcanic-sandy biosparite, Kōko Guyot. Scale bar in lower right is $1.0 \mathrm{~mm}$ long. Codiacean algae predominate; fragment in left center extends beyond field of photo for total length of $3 \mathrm{~mm}$. Upper left from it is a mollusk fragment. Foraminifers and grains of weathered basalt are also present, in microspar.

next in abundance. One biserial test of Bolivina sp. was observed, and one specimen, as seen in axial section with a flattened dorsal side, could be of the genus Cibicides.

The absence of orbitoid foraminifers, along with the high proportion of bryozoans to corals, suggests that the shallow water of Kōko Guyot during the early Eocene was not typical of the tropics.

Microspar makes up a large proportion of the thin section examined; unlike the great majority of carbonate rocks, in which grains between 4 and 20 microns (microspar) are uncommon, here microspar is more abundant than spar and micrite combined. From smear slides it is apparent that discoasters and other nannofossils compose much of the microspar. Most of the framework grains have been cemented first with microspar, in coatings about 20 microns thick, and thicker where grains touch one another. Microspar, micrite, and pyrite fill many foraminifer, bryozoan, and algal interiors. Spar is most common in the interiors of molds of codiacean algae and in patches between the larger grains that were not filled with the microspar.

Sample $308-4-1,130 \mathrm{~cm}$ is from a lower part of the core described above as Sample 308-4-1, $76 \mathrm{~cm}$. The sandstone sampled is a pebbly, calcareous, fossiliferous volcanic arenite. The small pebbles and sand grains of basalt are rounded and have been weathered or otherwise altered before deposition. The dominant cement is calcite microspar. Fragments of shallow-water fossils are the most common allochem grains, but oolites are also characteristic. Modal analyses of the nonpebble parts of two thin sections are in Table 3. A third section was scanned but not counted.

The volcanic component is more important in this sample (Figure 3) than in the higher sample from this site. The size of volcanic grains ranges from pebbles more than $2 \mathrm{~cm}$ in diameter to silt size. The median long 
TABLE 3

Composition of Fossiliferous Volcanic Sandstone 308-4-1, $130 \mathrm{~cm}$ (Eocene, Kōko Guyot) Based on 1000 Points Counted per Thin Section.

\begin{tabular}{lrr}
\hline & \multicolumn{2}{c}{ Thin } \\
& A & \multicolumn{1}{c}{ B } \\
\hline Volcanic grains & 586 & 588 \\
Augite & 2 & 6 \\
Plagioclase & 0 & 3 \\
Magnetite or ilmenite & 1 & 2 \\
Fossils & 83 & 99 \\
Intraclasts & 0 & 4 \\
Oolites & 22 & 20 \\
Pellets & 4 & 5 \\
Phosphate ovules & 2 & 2 \\
Spar $(>20 \mu \mathrm{m})$ & 31 & 9 \\
Microspar $(4<20 \mu \mathrm{m})$ & 262 & 258 \\
Micrite $(<4 \mu \mathrm{m})$ & 4 & 2 \\
Zeolite fringe & 2 & 0 \\
Pyrite & 1 & 2 \\
\cline { 2 - 2 } Total & 1000 & 1000 \\
\hline
\end{tabular}

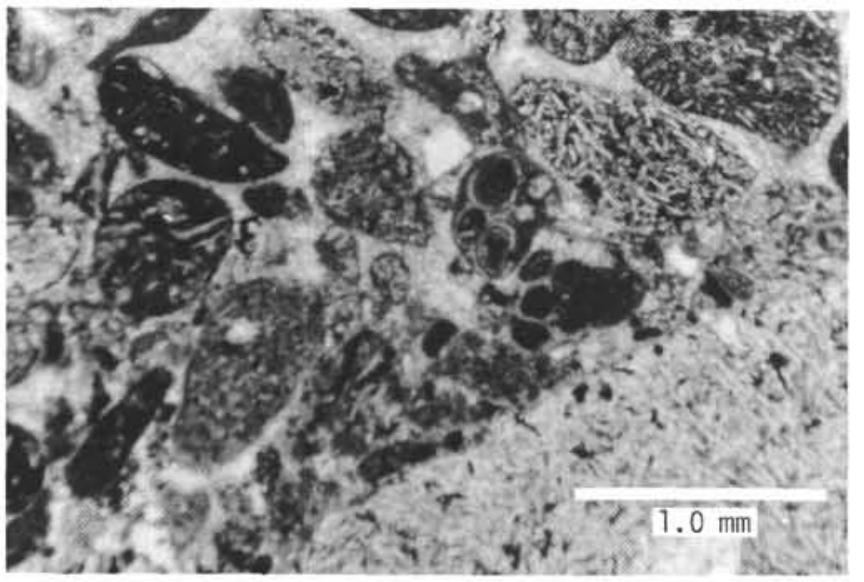

Figure 3. Photomicrograph, plain light, 308-4-1, $130 \mathrm{~cm}$. Eocene fossiliferous volcanic arenite, Kōko Guyot. Scale bar in lower right is $1.0 \mathrm{~mm}$ long. Scale bar is within a pebble of basalt. Elsewhere, a variety of rounded sand grains of basalt. Grain slightly upper right of center is grapestone of several fine grains of basalt with oolitic calcite coatings now all coated as one composite grain.

axis of 100 sand and silt grains measured on two thin sections, corrected $\times 1.15$ to account for the average smaller size of grains in random cuts compared to their actual dimensions, is $0.76 \mathrm{~mm}$, coarse sand. Width-tolength ratios are mainly 0.2 to 0.5 . Estimations of roundness on 400 grains disclosed that $30 \%$ of the volcanic grains are well rounded, with nearly another $40 \%$ rounded and $20 \%$ subrounded, leaving few angular to subangular grains. A high proportion of the volcanic grains are partly to largely replaced by birefringent clays and iron oxides suggestive of weathering. Some of the alteration was by palagonitization, and some other may also have been submarine, such as the calcite embayment of some grain edges. Zeolites and montmorillonite may have had either origin. The volcanic grains mainly have trachytic and intersertal textures, shown by the feldspar laths. Some feldspars are alkalic and many pyroxenes appear purplish-gray, suggesting that they are from alkalic basalts and related rocks. Many of the grains are crowded with opaques, and so probably account for the ilmenite values from X-ray analysis of adjacent samples.

The fossils are entirely of shallow-water type (Figure 4, Table 4), similar to those of Sample 308-1, $76 \mathrm{~cm}$ from the same core (Table 3). However, the green algae are of much less importance, both in the smaller size of their fragments and less total volume. Also, compared to the 76- $\mathrm{cm}$ sample, these foraminifers, red algae, and

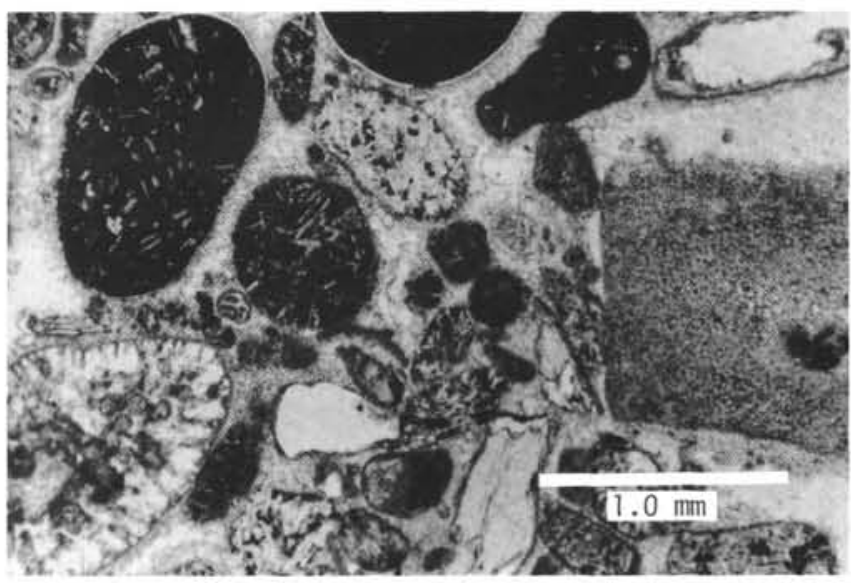

Figure 4. Photomicrograph, plain light, 308-4-1, $130 \mathrm{~cm}$. Eocene, fossiliferous volcanic arenite, Kōko Guyot. Scale bar in lower right is $1.0 \mathrm{~mm}$ long. Above it at right the optically continuous large grain of calcite is a piece of echinoid spine, with the central part showing gray and the rim clear. In the lower left is a grain of a codiacean alga, and at the left of the scale bar is an angular grain of pyroxene. Most other sand grains are of basalt. Some porosity is present in unfilled fossil molds (upper right) and between grains beyond their fringe of "picket-fence" calcite cement (center of left edge).

TABLE 4

Biogenic Constituents of Fossiliferous Volcanic Sandstone 308-4-1, $130 \mathrm{~cm}$ (Eocene, Kōko Guyot) Based on 200 Point Counts per Thin Section

\begin{tabular}{|c|c|c|c|}
\hline & \multicolumn{2}{|c|}{ Thin Section } & \multirow{2}{*}{$\begin{array}{c}\mathrm{A}+\mathrm{B}, \text { in } \\
\% \text { (rounded) }\end{array}$} \\
\hline & A & B & \\
\hline Foraminifers & 71 & 75 & 36 \\
\hline Green algae & 39 & 45 & 21 \\
\hline Red algae & 41 & 15 & 14 \\
\hline Bryozoans & 10 & 22 & 8 \\
\hline Mollusks & 14 & 25 & 10 \\
\hline Ostracodes & 3 & 2 & 1 \\
\hline Corals & 2 & 1 & 1 \\
\hline Echinoids & 8 & 10 & 4 \\
\hline Unknown & 12 & 6 & 4 \\
\hline Total & 200 & 200 & $99 \%$ \\
\hline
\end{tabular}


echinoid fragments are more abraded, and bryozoans are more fragmentary. In addition to the calcareous fossils listed in Table 4, some small angular pieces of phosphorite, probably fish-bone debris, were observed, but never fell under the crosshairs during traverses. Similarly, a few green grains of glauconite are not tabulated, although they were seen.

Many oolites are present. Some oolite cores are fossil fragments. Mainly, however, cores are basalt sand grains, with oolite coatings 0.03 to $0.05 \mathrm{~mm}$ in thickness, making a relatively thin part of the whole grain. In two slides there are representatives of oolites within oolite (grapestone). Other allochemical grains present include several pellets in each of the slides, and one slide has three small intraclasts, of fossil plus oolite plus basalt.

About one-quarter of the specimen is calcite microspar. Some of it may be nannofossils and recrystallized nannofossils, but most of it has a radiating habit around the framework grains and so is cement. Sparry calcite fills a few intergranular spaces and molds of green algae. The usual microspar fringe is thin or absent in one patch of grains (Figure 5), where a thin fringe of zeolite acts as cement. Some pyrite, mainly inside foraminifer tests and green and red algae, was identified by reflected light.

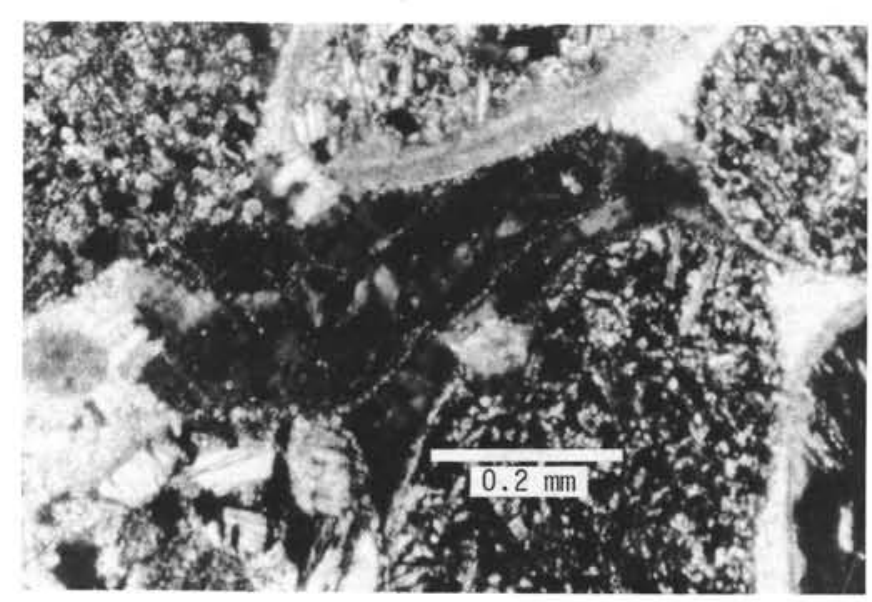

Figure 5. Photomicrograph, plain light, $308-4-1,130 \mathrm{~cm}$. Eocene, fossiliferous volcanic arenite, Kōko Guyot. Scale bar below center is $0.2 \mathrm{~mm}$ long. Rounded sand grains of basalt mainly are fringed with calcite cement, as at upper center and at right. Grains in center (e.g., at left end of scale bar) are thinly rimmed with zeolite.

\section{ARCHIPELAGIC APRON OF HAWAIIAN RIDGE}

Core 3 of Site 311, represented by Sample 311-3, CC, is Oligocene in age. This sandstone is a fine-grained, zeolite-cemented, volcanic arenite. Angular grains of hyaloclastite glass, now altered to montmorillonite, are most numerous. Other detritus in this turbidite bed is also of volcanic origin and includes grains of basalt, pyroxene, and plagioclase (Table 5). Grains are rimmed with celadonite, and the remaining pore space was filled with phillipsite.

Nearly $40 \%$ of the rock is composed of sand-sized grains of microcrystalline montmorillonite. The grains
TABLE 5

Composition of Altered Volcanic Sandstone 311-3, CC (Oligocene, from Archipelagic Apron of Hawaiian Ridge about $250 \mathrm{~km}$ West of Midway Islands) Based on 1000 Points Counted on Thin Section

\begin{tabular}{lr}
\hline Montmorillonite-replaced glass grains & 386 \\
Celadonite-replaced glass grains & 26 \\
Palagonite alteration of glass grains & 2 \\
Basalt grains & 148 \\
Nearly opaque grains of basalt and glass & 19 \\
Pyroxene grains with hematite alteration & 37 \\
Pyroxene grains & 18 \\
Plagioclase grains & 10 \\
Early cement and alteration & \\
$\quad$ (celadonite rims) & 231 \\
Late cement & \\
$\quad$ (phillipsite fillings between rimmed grains) & 121 \\
Calcite replacement & 2 \\
\cline { 2 - 2 } Total & 1000 \\
\hline
\end{tabular}

range in size mainly from 0.1 to $0.6 \mathrm{~mm}$, with a median of about $0.19 \mathrm{~mm}$ (corrected for the smaller average grain size in sectioned grains). Under the binocular microscope the grains appear to be prismatic to tabular, even cube-like. Nearly all the grains are angular. In thin section, most grains have slightly concave to straight to slightly convex sides, enclosing irregular polygons. Others have more strongly concave surfaces, which in many instances obviously are vesicle walls (Figure 6). None of the grains has the splintery, slender, curved shapes typical of pyroclastic fragments, although the graded bedding in these cores indicates redeposition by turbidity currents, and the transportation may have broken up shards and spicular grains and so destroyed evidence of an original pyroclastic source. On the other hand, because virtually all these grains have the blocky shape indicative of hyaloclastite, almost certainly that was their origin upslope from the site of deposition. They were sideromelane glass fragmented by the rapid quenching of a submarine eruption. The two thin sec-

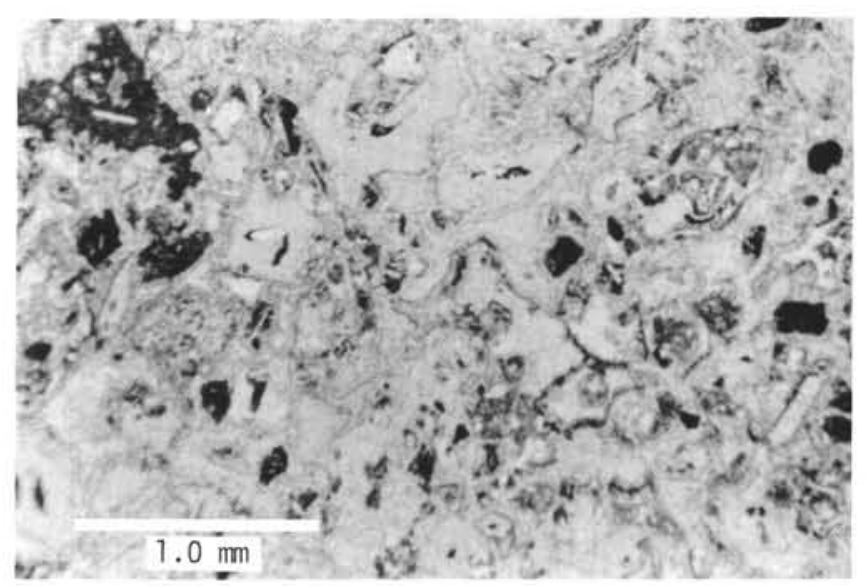

Figure 6. Photomicrograph, plain light, 311-3, CC. Late Oligocene hyaloclastite arenite, northwest Hawaiian Ridge. Scale bar in lower left is $1.0 \mathrm{~mm}$ long. Light grains are of montmorillonite-replaced hyaloclastite glass, rimmed with celadonite. Dark grains are of basalt. 
tions examined show only a few rare and doubtful examples of fragmentation after the cementing rims started to grow, suggesting that the glass was moved downslope to Site 311 very shortly after eruption. There it altered, probably through a palagonite state, to the entirely birefringent present stage.

Next in importance are sand grains of basalt, which comprise about $15 \%$ of the sediment. Basalt sand grains have nearly the same size and shape as the montmorillonite aggregates described above; they are on the average slightly smaller and less angular. Most of the basalt is altered, though a few grains have patches of glass and several have unaltered plagioclase phenocrysts. Nearly all basalt grains have distinct rims of celadonite or nontronite cement.

Some lithic grains are so dark with fine-grained opaque minerals that identification is nearly impossible. With the aid of the condensing lens, part of these appear to be heavily altered basalt. Others seem to be unaltered or devitrified tachylite, streaky with opaque dust. A few of these grains are the only ones in the thin sections with a slender, shard-like shape.

Pyroxene grains are a significant component of the sediment. About two-thirds of the pyroxene grains are characterized by extensive hematite alteration, especially along the intersection of cleavages. They are augite, and some show fairly strong dispersion. Plagioclase grains are less common. The waxy, dark green interiors of the altered-glass grains have waxy, translucent white to green rims about $0.015 \mathrm{~mm}$ thick. In thin section the interiors are pale yellowish-green. Some have fine cracks, in a blocky pattern. Crossed polarizers and high magnification disclose aggregates of interlocking to vermiform grains a few microns in size, with speckled, pinpoint birefringence and undulose extinction. The rims, second in importance in the volume of the rock, are lamillar to mammiform, and mainly pale yellow to moderate yellow. Some rims are banded, with white, fibrous fringes outside the yellow. The X-ray and optical observations indicate that the grain interiors are montmorillonite and their rims are celadonite (and nontronite?), with the thin white fringe, where present, probably zeolite. The rims are mainly cement, as they coat basalt and other grains in addition to the ones of altered glass. But their contact with the montmorillonite of the altered-glass grains is commonly fuzzy to embayed, suggesting that the inner rims may be partly a replacement or another type of alteration feature. In several instances grains appeared to be replaced entirely by celadonite. However, that may be an artifact of the thin section, where the slice is entirely in celadonite cement parallel to a grain surface. These grains were tabulated separately.

Zeolite filled the pore spaces remaining after the rims formed. The zeolite cement appears to be entirely phillipsite. Traces of analcime were detected in X-ray analysis of adjacent samples, but were not identified optically in this one. Zeolite is present as blocky masses with a slightly radiating fibrous habit ("incipient spherulitic"), and interlocking edges.

Both thin sections examined have a few grains of orange palagonite penetrated by irregular to rounded blotches of yellow-orange nontronite? and iron oxide. One section has a patch of calcite replacing grains and cement.

A $4.5 \times 6.0 \mathrm{~cm}$ thin section including both a crossbedded and a parallel-bedded part of Core 3 was also examined $(311-3-1,125 \mathrm{~cm})$. As with the core-catcher samples, the sediment is dominated by angular grains of hyaloclastite glass, now altered to montmorillonite. Lamination is shown mainly by orientation of elongate grains (Figure 7) and partly by layers of differing size or composition. Compared with the parallel-bedded part of this thin section and with the turbidite of Sample 3113 , CC, grains in the cross-bedded part have more red oxide alteration. Poikolitic crystals of calcite cement that corrode grain boundaries are also characteristic of the cross-bedded part (Figure 8).

Core 5 includes coarse volcanic-rich sediments. A 3.0 $\times 6.0 \mathrm{~cm}$ thin section from $311-5-1,96 \mathrm{~cm}$ is of a poorly sorted hyaloclastite. Grains coarser than $4 \mathrm{~mm}$ make up about $20 \%$ of the grains. Mainly these are fragments of volcanic rocks that originally were vesicular, glassy, and porphyritic, but now virtually all are filled by or replaced by montmorillonite and some minor iron oxides. The clustering and grain outlines suggest that the phenocrysts were glomerocrysts of olivine or pyroxene. Some of the large grains are of basalt with the interstices between feldspar microlites and granular to sheaf-like pyroxene filled with strings of opaque grains and glass or altered glass in intersertal texture.

The sand-sized grains are largely of pale golden brown palagonite, but grains of glass, montmorillonitereplaced glass, and intersertal basalt are also common. There are a few grains of pyroxene. All these grains except the pyroxene are sharply angular, and all are rimmed with fibrous pale grayish-green celadonite in coats about $15 \mu \mathrm{m}$ thick. In patches along some of the palagonite rims, celadonite has penetrated an equiva-

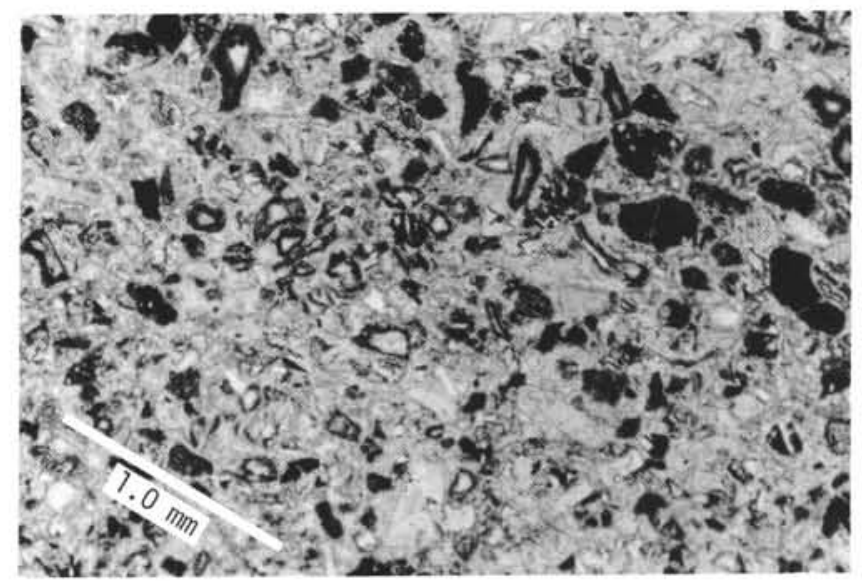

Figure 7. Photomicrograph, plain light, 311-3-1, $125 \mathrm{~cm}$. Late Oligocene hyaloclastite arenite, northwest Hawaiian Ridge. Scale bar in lower left is $1.0 \mathrm{~mm}$ long, and is parallel to cross-lamination of the rock. Layering shown by composition (light grains mainly altered hyaloclastite; dark grains mainly basalt), grain size, and grain shape. 


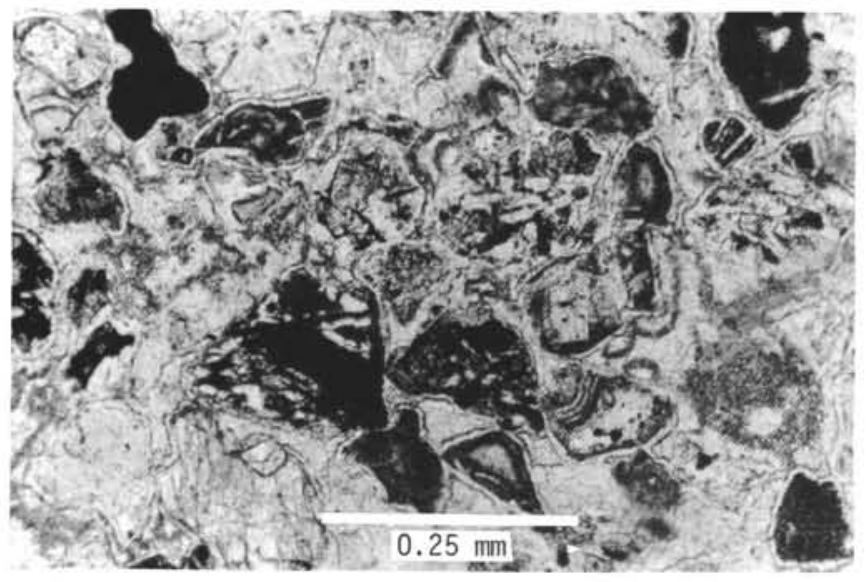

Figure 8. Photomicrograph, plain light, 311-3-1, $125 \mathrm{~cm}$. Late Oligocene hyaloclastite arenite, northwest Hawaiian Ridge. Scale bar in lower center is $0.25 \mathrm{~mm}$ long. Light patch at left end of scale bar is calcite cement. Large grain above it, patterned in black and white, is pyroxene largely altered by hematite. Smaller grayish grains above it and extending to the right were hyaloclastite glass, now replaced by celadonite grading inwards to montmorillonite; thin clear fingers appear to be a zeolite.

lent depth into the grains as an alteration product. Anhedral zeolite fills the remainder of the intragranular space.

The sediment is interpreted as a hyaloclastite that has had a modest amount of reworking to remove the finest sizes of glass, but not enough to sort out the medium from the coarser grains.

\section{EASTERN MID-PACIFIC MOUNTAINS}

Campanian sediments at Site 313 have a varied volcanic component. Sample 313-24-2, $54 \mathrm{~cm}$ is a calcareous, fossiliferous, volcanic siltstone. It is well lithified and very poorly sorted. In hand specimen the rock is finely laminated $(<1 \mathrm{~mm}$ with some layers up to $5 \mathrm{~mm}$ ). The laminae are distinguished by shades of greenish-gray color. The majority of bedding planes are horizontal, although some do form indistinct ripples and cross beds. The rock probably represents the upper part of a larger unit deposited by a turbidity current.

In thin section the rock is poorly sorted with clasts ranging in size from $20-200 \mu \mathrm{m}$. The laminations are easily distinguished by the nature of the matrix and cement; there are carbonate-rich layers and authigenic clay-rich layers. Micritic carbonate cements some layers that contain a concentration of foraminifer tests. The foraminifers are both planktonic and benthonic and have their long axis parallel to bedding. Low birefringent smectite with minor zeolite (phillipsite) cements the remaining laminae. There is a concentration of volcanic detritus in these laminae relative to the adjacent carbonate-rich laminae. Opaque minerals are present but the laminations are not due to a segregation of these minerals. The composition, based on 500 point counts, is listed in Table 6 .
TABLE 6

Composition of Calcareous Voleanic Siltstone 313-24-2, $54 \mathrm{~cm}$ (Campanian, Eastern MidPacific Mountains) Based on 500 Points Counted on Thin Section

\begin{tabular}{|c|c|}
\hline & $5 \%$ \\
\hline $\begin{array}{l}\text { Basaltic fragments } \\
\text { Foraminifers }\end{array}$ & 20 \\
\hline Opaques & 42 \\
\hline Palagonite & $<1$ \\
\hline Radiolaria & $<1$ \\
\hline Augite & $<1$ \\
\hline $\mathrm{K}$-feldspar & $<1$ \\
\hline Plagoiclase & $<1$ \\
\hline Matrix: calcite (micrite) & 18 \\
\hline phillipsite & 3 \\
\hline smectite & 11 \\
\hline Total & $100 \%$ (rounded) \\
\hline
\end{tabular}

The basaltic fragments are altered and generally rounded. Their textures were used for identification. The opaque grains are angular but with high sphericity. They are of volcanic origin, being present in some basaltic clasts. The thin section contains some fractured and subrounded pieces of palagonite indicating its formation elsewhere and subsequent transportation to this site.

Many of the foraminifer tests are filled with authigenic smectite, and some contain a low-birefringent, low-relief authigenic crystal which has the optical properties of $\mathrm{K}$-feldspar (Figure 9). The rarity of these grains prevented positive identification, however, the Xray sample from this core identified K-feldspar. The foraminifer tests also contain carbonate rhombs up to $25 \mu \mathrm{m}$ in size. Angular, brownish augite (size $125 \mu \mathrm{m}$ ) is present together with rare plagioclase (size $30 \mu \mathrm{m}$ ) crystals.

This sample contains no volcanic glass nor any spherulitic palagonite that is common in coarse-grained rocks deeper in this hole. The rock represents the topmost volcanic strata and is overlain by a carbonate sequence.

Sample 313-25-2, $146 \mathrm{~cm}$ comes from the lower part of a graded turbidite and is a well-lithified calcareous volcanic sandstone (Table 7). The sorting is poor with the grains averaging $2 \mathrm{~mm}$ in size. The fabric is uniform with no orientation of the fragments.

The basaltic clasts are subrounded and have high sphericity in contrast to the palagonite which is angular and has lower sphericity (Figures 10 and 11). The glauconite occurs as pale green clay lumps and probably represents fecal pellets. Phillipsite occurs in radiating sheaves lining voids in the matrix as well as forming spheres in the palagonite.

Rock $(313-25-4,68 \mathrm{~cm})$ is a well-lithified calcareous volcanic sandstone. It was sampled from the base of a turbidite and consists of randomly oriented fragments of volcanic material in a calcareous clayey matrix.

In thin section the size of the clasts ranges from 2-10 $\mathrm{mm}$ with an average of $5 \mathrm{~mm}$. Sorting is poor.

An unusual feature of this rock (Table 8 ) is the presence of rounded fragments of sparry carbonate with individual crystals up to $600 \mu \mathrm{m}$. The spar has been transported to its present site. 


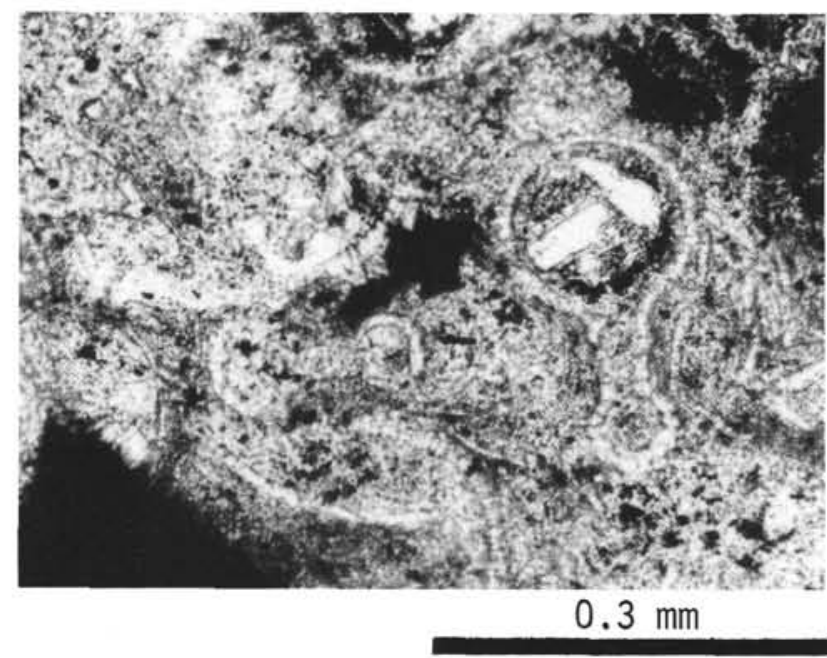

Figure 9. Photomicrograph, plain light, 313-24-2, $54 \mathrm{~cm}$. Authigenic low-birefringent mineral growing inside foraminifer test in micritic matrix. Is probably $K$ feldspar.

TABLE 7

Composition of Volcanic Sandstone 313-24-2, $146 \mathrm{~cm}$ (Campanian, Eastern Mid-Pacific Mountains) Based on 500 Points Counted on Thin Section

\begin{tabular}{lc}
\hline & $10 \%$ \\
Foraminifers & 8 \\
Basalt fragments & 38 \\
Palagonite & 6 \\
Augite & 4 \\
Plagioclase & 14 \\
Phillipsite & $<1$ \\
Glauconite & 20 \\
Matrix: as clayey micrite & $100 \%$ (rounded) \\
\cline { 2 - 2 } Total &
\end{tabular}

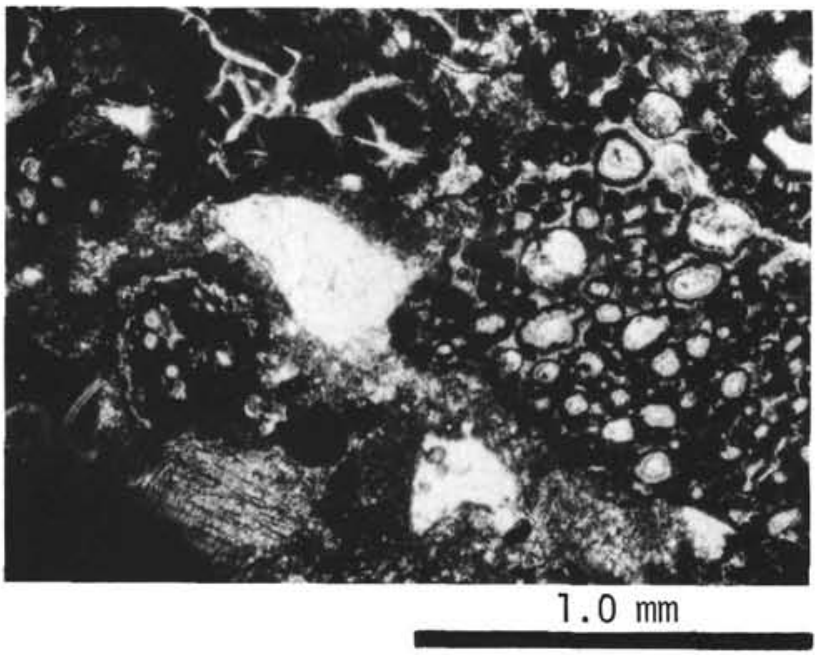

Figure 10. Photomicrograph, plain light, 313-25-2, 146 $\mathrm{cm}$. Angular fragments of palagonite containing vugs lined with pale green smectite and radiating phillipsite crystals. The phillipsite sheafs in the center are partly filling $a$ void in the rock.
TABLE 8

Composition of Calcerous Volcanic

Sandstone 313-25-4, $68 \mathrm{~cm}$ (Cam-

panian, Mid-Pacific Mountains)

Based on $\mathbf{5 0 0}$ Points Counted on Thin Section

\begin{tabular}{lr}
\hline Plagioclase & 10 \\
Augite & 3 \\
Foraminifers & 3 \\
Palagonite & 26 \\
Phillipsite & 8 \\
Spar & 6 \\
Basalt fragments & 4 \\
Matrix: micrite and clay & 40 \\
\cline { 2 - 2 } Total & $100 \%$ \\
\hline
\end{tabular}

The matrix is brown, nearly opaque, and contains foraminifer tests $2-200 \mu \mathrm{m}$ in size.

The spherulitic palagonite is subrounded in outline, but has spherical areas filled with smectite or radiating sheaves of zeolite and phillipsite. Some postdepositional fractures in the rock have now been filled by phillipsite.

Large, up to $6 \mathrm{~mm}$, angular crystals of plagioclase and augite contrast with the generally subrounded nature of the other fragments.

Rock $(313-27-2,15 \mathrm{~cm})$ is a lithified calcareous volcanic sandstone containing angular to rounded clasts up to $2 \mathrm{~cm}$ in size with an average diameter of $3 \mathrm{~mm}$. The clasts have no orientation.

Foraminifers together with finer $(<60 \mu \mathrm{m})$ volcanic detritus and some nannofossils are found in the matrix which dominates this rock (Table 9). The matrix is a clay-rich micrite with the carbonate probably representing recrystallized nannofossils.

The basalt fragments are generally rounded while the plagioclase and augite crystals are angular and have lower sphericity. One augite crystal is $3 \mathrm{~mm}$ in length and unaltered. The palagonite fragments generally contain spherical areas of pale green smectite. One rock

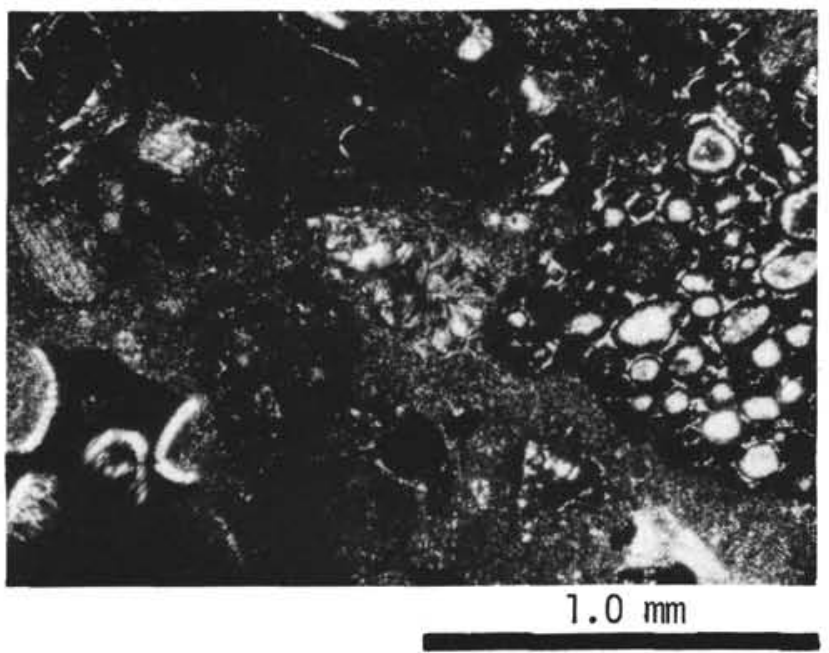

Figure 11. Photomicrograph, crossed miols, 313-25-2, $146 \mathrm{~cm}$. Same as Figure 10. 
TABLE 9

Composition of Calcareous Volcanic Sandstone 313-27-2, $15 \mathrm{~cm}$ (Campanian, MidPacific Mountains) Based on 500 Points Counted on Thin Section

\begin{tabular}{lc} 
Augite & $3 \%$ \\
Plagioclase & 8 \\
Basalt fragments & 9 \\
Palagonite & 31 \\
Porcellanite & $<1$ \\
Foraminifers & 4 \\
Matrix: micrite, clay & 44 \\
\cline { 2 - 2 } Total & $100 \%$ (rounded) \\
\hline
\end{tabular}

fragment is an angular piece of porcellanite which was silicified prior to transport to its present position.

A specimen sampled at $313-29-4,100 \mathrm{~cm}$ is a lithified calcareous volcanic sandstone. It is poorly sorted with fragment sizes ranging up to $600 \mu \mathrm{m}$. The fragments are not oriented. Composition is shown in Table 10. It contains rounded, spherical, bright green glauconite pellets

TABLE 10

\begin{tabular}{lc}
$\begin{array}{c}\text { Composition of Calcareous Volcanic Sandstone } \\
\text { 313-29-4, 100 cm (Campanian, Mid-Pacific } \\
\text { Mountains) Based on 500 Points Counted on } \\
\text { Thin Section }\end{array}$ \\
\hline \multicolumn{2}{c}{$\begin{array}{c}\text { Toraminifers } \\
\text { Basaltic fragments }\end{array}$} \\
Opaques & $29 \%$ \\
Plagioclase & 5 \\
Augite & 2 \\
Glauconite & 1 \\
Palagonite & $<1$ \\
Matrix: micrite and clay & 38 \\
Total & $100 \%$ (rounded)
\end{tabular}

up to $400 \mu \mathrm{m}$ in size. The fresh plagioclase and augite are angular and generally $300 \mu \mathrm{m}$ in size.

The rock is characterized by brownish opaque material which, under strong illumination, was identified as altered basaltic fragments. The identification is based on textures. These fragments are quite uniform in size, about $500 \mu \mathrm{m}$, and cause the rock to be better sorted than the other sandstones described from this site.

The foraminifer tests are both planktonic and benthonic species and are now filled with clayey micrite. The near absence of palagonite is unusual considering its abundance in most other similar samples.

A calcareous volcanic sandstone was sampled at 313$30-1,44 \mathrm{~cm}$. In thin section the grain size ranges up to 5 $\mathrm{mm}$ with an average of $2 \mathrm{~mm}$. There are also many grains with a size of approximately $600 \mu \mathrm{m}$. The grains have moderate sphericity and are not oriented. In general, the smaller grains are well rounded (Figure 12). The composition, determined by 500 point counts, is listed in Table 11.

The clayey micritic matrix contains the opal tests of radiolarians. Frequently the radiolarians are well preserved, and the opal is isotropic and has not recrystallized to opal-CT or chalcedony. The rock contains an angular fragment of chert in which chalcedony has re-

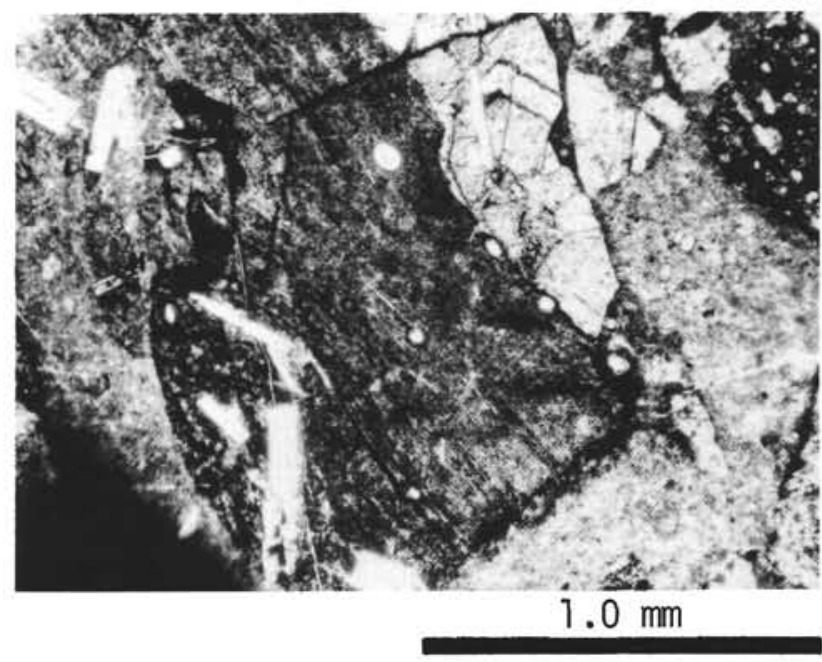

Figure 12. Photomicrograph, plain light, 313-30-1, 44 $\mathrm{cm}$. Angular fragments of basalt and palagonite. The palagonite contains spherical areas filled radially with green smectite and the zeolite phillipsite matrix is micritic clay.

TABLE 11

Composition of Calcareous Volcanic Sandstone 313-30-1, $44 \mathrm{~cm}$ (Campanian, Mid-Pacific Mountains) Based on 500 Points Counted on Thin Section

\begin{tabular}{lc}
\hline Palagonite & $40 \%$ \\
Basalt fragments & 18 \\
Foraminifers & 2 \\
Radiolaria & $<1$ \\
Pumice & $<1$ \\
Plagioclase & $<1$ \\
Augite & $<1$ \\
Phillipsite & $<1$ \\
Green smectite & $<1$ \\
Matrix: micrite, clay, nannofossils & 39 \\
\cline { 2 - 2 } Total & $100 \%$ (rounded) \\
\end{tabular}

placed foraminifer tests and the matrix is opal-CT and chalcedony. The angular fractures outlining this chert suggest it is older than the present rock.

A feature of this rock is the partial replacement of many grains of palagonite and basalt by spar and microspar. Textural relationships suggest this replacement is in situ for larger angular grains and is a relic from the source for smaller rounded grains.

Rock (313-30-3, $64 \mathrm{~cm}$ ) from the base of a turbidite, is a calcareous volcanic sandstone. It is compact, lithified, and poorly sorted. The lithic fragments have no particular orientation and range in size up to $1 \mathrm{~cm}$.

In thin section most grains are subrounded with high sphericity except for plagioclase and augite crystals which are angular.

The palagonite (Table 12) has the characteristic spherulitic texture, the spherules being filled with a pale green smectite or phillipsite or both. The basalt fragments display many textures including felted, porphyritic, aphanitic, and intersertal. Basaltic glass also occurs and the fragments are set in a calcareous clay containing foraminifera and radiolarians (Figure 13). 
TABLE 12

Composition of Calcareous Volcanic Sandstone (Campanian Mid-Pacific Mountains)

Based on 500 Points Counted on Thin Section

\begin{tabular}{lc}
\hline Palagonite & $24 \%$ \\
Basalt fragments & 20 \\
Augite & 3 \\
Plagioclase & 4 \\
Pumice & 2 \\
Foraminifers & 2 \\
Radiolaria & $<1$ \\
Phillipsite & 2 \\
Matrix: clay, micrite & 42 \\
\cline { 2 - 2 } Total & $100 \%$ (rounded) \\
\hline
\end{tabular}

A moderately well-lithified, impure limestone was sampled at $313-41-5,57 \mathrm{~cm}$. It is very poorly sorted and contains no orientation or lamination.

Basalt fragments and palagonite (Table 13) are severely altered, but the plagioclase and augite are clear and

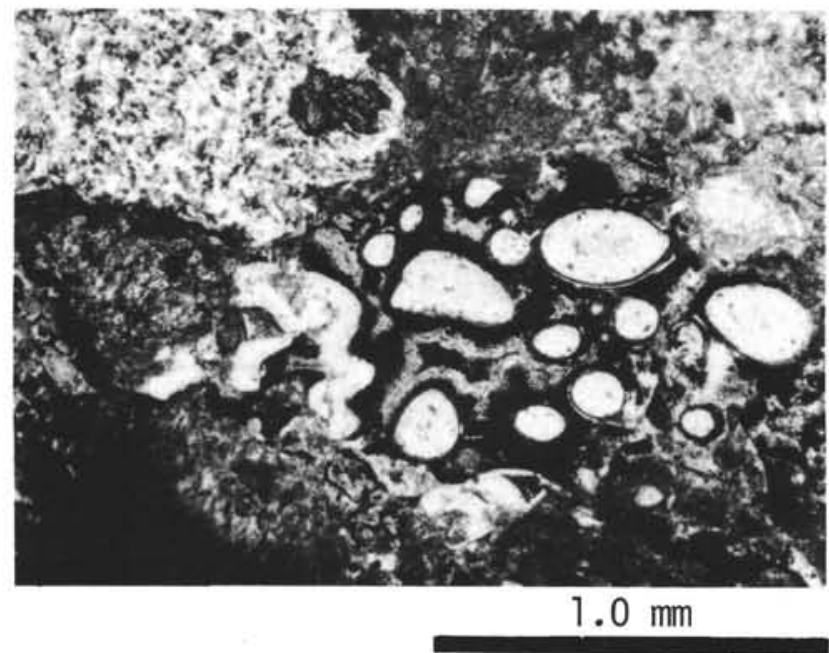

Figure 13. Photomicrograph, plain light 313-30-3, 64 $\mathrm{cm}$. Plagioclase lath set in a fragment of partly palagonized glass. Flow lines occur in the glass. Radiolarians and foraminifer tests are common in the matrix between the glass and volcanic fragments.

unaltered. The basalt is generally more rounded than the other lithic fragments. The size of the lithic fragments is: opaques $50 \mu \mathrm{m}$; basalt fragments $200-300 \mu \mathrm{m}$; palagonite $50-100 \mu \mathrm{m}$; and plagioclase $100-150 \mu \mathrm{m}$.

This rock could be the burrowed top of a turbidite where the finer-grained calcareous material has been mixed with some of the underlying coarser volcanics.

Rock $(313-41-5,121 \mathrm{~cm})$ is a semilithified volcanic ash forming a $2-\mathrm{cm}$ bed in a limestone. It is composed of randomly oriented pale greenish-brown to colorless basaltic glass (r.i. 1.59). Some of the glass is shardshaped, some is platey, and some forms angular grains (Figure 14). Minor constituents are radiolarians (as opal-A), planktonic foraminifers, and nannofossils. Clay (smectite) coats the grains and forms the cement (Figure 15). Some of the grains contain plagioclase laths and rare augite crystals and many have vesicles. The grain size ranges from $10-200 \mu \mathrm{m}$ with some rare pieces of pumice slightly larger.
TABLE 13

Composition of Impure Limestone 313-41-5, $57 \mathrm{~cm}$ (Campanian, Eastern Mid-Pacific Mountains) Based on 500 Points Counted on Thin Section

\begin{tabular}{lr}
\hline Foraminifers & $6 \%$ \\
Plagioclase & 4 \\
Augite & 2 \\
Palagonite & 9 \\
Basalt fragments & 12 \\
Opaques & 7 \\
Phillipsite & 4 \\
Micrite (including nannofossils & \\
$\quad$ and associated clay) & 56 \\
\cline { 2 - 2 } Total & $100 \%$ \\
\hline
\end{tabular}

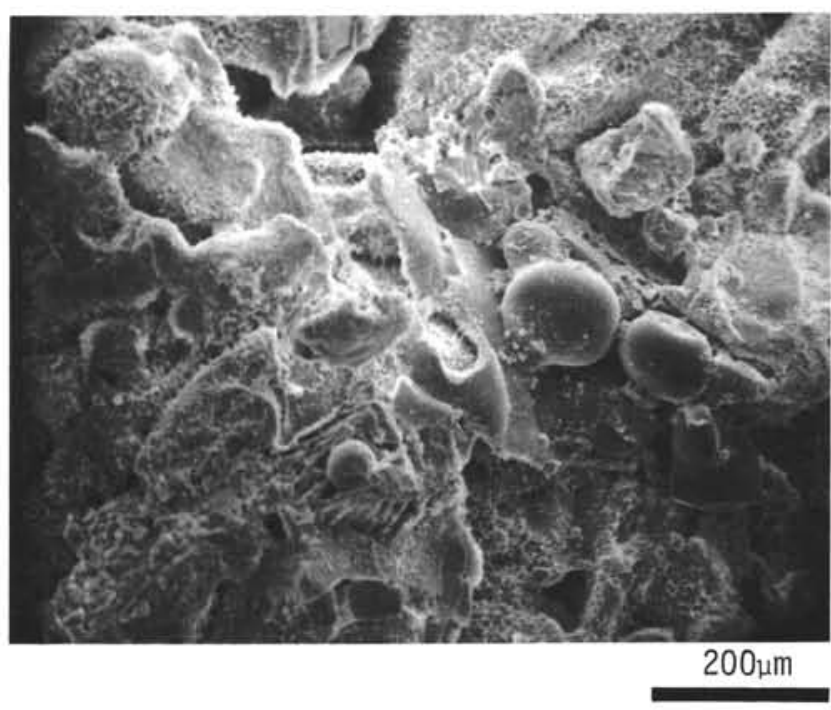

Figure 14. Scanning electron microscope photo, 313-41-5, $121 \mathrm{~cm}$. Fracture surface of a weakly lithified ash layer. The glass has various shapes including botryoidal lumps on thin plates.

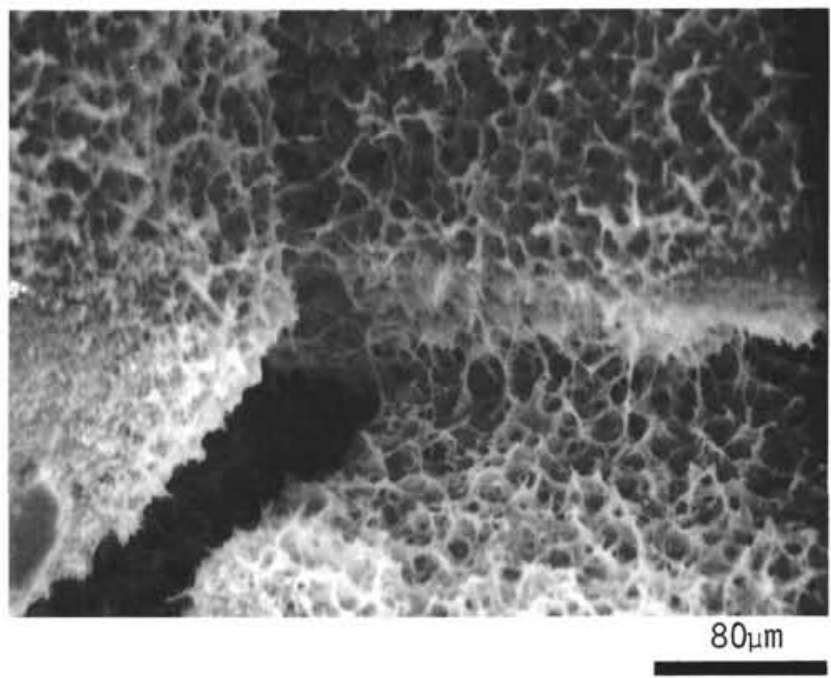

Figure 15. Scanning electron microscope photo, 313-41-5, $121 \mathrm{~cm}$. Fracture surface of weakly lithified black ash layer. Authigenic smectite coats the shard fragments and forms the cement. 
One lamina (variable thickness of 2 to $4 \mathrm{~mm}$ ) consists of coarser glass fragments and is also partly altered to palagonite.
This ash layer is only 10 meters above the basalt in which the hole was terminated and probably reflects the time of active volcanism nearby. 